6. Сазонова Ю. О. Сучасна релігійна преса Донбасу: стан, функції, перспективи розвитку. Філологічні обрії: збірник наукових пращь молодих учених України. 2011. Вип. 5. С. 160-166.

DOI https://doi.org/10.30525/978-9934-26-039-1-86

\title{
ЗАГОЛОВКОТВОРЕННЯ ЯК ВАЖЛИВА СКЛАДОВА ЖУРНАЛІСТСЬКОГО ТЕКСТУ: ЯК ПОЗБУТИСЯ НЕКЛІКАБЕЛЬНИХ МЕДІАНАЗВ
}

\author{
Шульська Н. М. \\ кандидат філологічних наук, дочент, \\ доцент кафедри сочіальних комунікацій \\ Волинського національного університету імені Лесі Украӥнки \\ м. Луцьк, Україна

\section{Римар Н. Ю.} \\ кандидат філологічних наук, \\ дочент кафедри славістичної філологї, педагогіки \\ та методики викладання \\ Білоцерківського національного аграрного університету \\ м. Біла Церква, Київська область, Україна
}

Зацікавлення інформаційним наповненням будь-якого сучасного масмедіа відбувається передовсім через оригінальну, влучну, логічну палітру заголовкової системи. Відомо, що заголовок - невіддільний конституент журналістського тексту, який виразно «працює» на читача, керує його увагою. Зробити заголовковий комплекс цікавим та інтригуючим, допомогти читачеві зорієнтуватися у порушеній проблемі, точно передати зміст і використати мінімум словесного матеріалу важливе завдання сучасних компетентних 3МI.

У вітчизняних дослідженнях медіаназви проаналізовано у кількох аспектах: 1) розглянуто особливості iï архітектоніки (М. Ріпей [6], В. Шевченко [11- 12]); 2) з'ясовано лексико-семантичні та лексикостилістичні особливості (Н. Шульська [13-14], Г. Шаповалова [10], Л. Солодка [8-9]); 3) описано як засіб впливу на суспільну свідомість (В. Шевченко [11]); 4) представлено проблему способів та засобів увиразнення (Л. Майборода [1-4]); 5) акцентовано увагу на функціях заголовкового комплексу (В. Михайленко [5]) тощо. 
Незважаючи на різницю між регіональними інтернет-3МІ, при виборі заголовків журналісти припускаються однакових, типових помилок, одна з них - повтори в медіаназвах. Нерідко навіть в одному й тому ж випуску видання трапляються заголовки, що повторюються майже повністю. Ще частіше у стрічці з'являються заголовки з повтором одного чи декількох слів. Це свідчить або про обмеженість словникового запасу редакційних працівників, або про їхню неуважність. Нерідко натрапляємо й на однакові побудови та форми заголовків. Досить переглянути новинну стрічку за день, щоб помітити й вилучити всі повтори в заголовках.

Неодноразово трапляються новинні матеріали із занадто довгими заголовками, що важко сприймаються, і взагалі зникає бажання читати такий текст. Не менше уваги вимагає й постановка заголовка поруч 3 ілюстрацією, іноді виникає невдале поєднання заголовка та ілюстрацій. Поширений недолік багатьох видань - суміш стилів оформлення заголовків. Відомо, що існує два ефекти у читацькому сприйманні заголовків.

Ефект посиленого очікування, що виникає тоді, коли заголовок незрозумілий, але привертає увагу, й ефект обдуреного очікування, коли заголовок за змістом не збігається з текстом. В обох випадках заголовки можуть викликати непередбачену реакцію на текст - від захопленого читання до відмови читати текст і негативної оцінки автора чи редакції. Серед недоліків щодо організації заголовкових комплексів можна назвати: 1) бідне членування змісту, що обмежується здебільшого підсистемою «заголовок-текст» або «рубрика-заголовок-текст»; 2) одноманітність членування змісту (рубрика-заголовок-вріз-текст); 3) функціональна обмеженість заголовкового комплексу: переважно використовується інформативна функція; 4) атематичність і алогічність, що виникає на стикові рубрик і заголовків, заголовків і текстів, заголовків, лідів і текстів і т.п.; 5) плеонастичність компонентів заголовкового комплексу, тобто їх змістове дублювання; 6) незрозумілість і нечіткість назв [11, с. 389].

Серед ознак, що знижують клікабельність заголовків у проаналізованих нами інтернет-виданнях, ми вказуємо на такі:

1. Загаловок надто великий, складний, не лаконічний, напр.: «Більше $60 \%$ боржників сплачують борг після відключення, - ПАТ «Волиньгаз»« («Волинська правда», 26.10.2018); ««Момент для намої Церкви, як ніколи», - митрополит УПЦ про Томос автокефалію» («Волинська правда», 22.10.2018); «Волинські спещпризначениі вирушили в чергову ротачію в зону проведення ООС» («Волинь Онлайн», 01.10.2018); «Держенергоефективності та СБРР закріпили співпраџюю у сфері 
сертифікації енергоефективності будівель в Онлайн», 23.09.2018); «Взяли під варту мешкания Дніпропетровщини, який пограбував пенсіонерку на Волині» («Волинь Онлайн, 19.10.2018).

2. Заголовок містить нагромадження цифр і відсотків: «Більше $60 \%$ боржників сплачують борг після відключення, - ПАТ «Волиньгаз»« («Волинська правда», 26.10.2018).

3. Подання в заголовку часто незрозумілої абревіатури: «Волинські митники допомагали нелегально ввезти сотні автівок, - ГПУ» («Волинська правда», 26.10.2018); «У Ковельському МТМО - новітне обладнання (ФОТО)» («Волинська правда», 22.10.2018); «На Волині на хабарі викрили посадовиів ДСНС та Держпродспоживслужби. Фото» («Волинь Онлайн», 07.10.2018); «В унікальному МСУМКУ влаштували паті для луцьких вчителів» («Таблоїд Волині», 19.10.2018).

4. Уміщення незрозумілих імен та прізвищ: «РПЦ $є$ продовження російських спеислужб», - Габсбург» («Волинська правда», 23.10.2018).

5. Заголовок повідомляє суть усієї новини: «Волинянка злетіла автівкою у кювет та врізалась в дерево: дівчина - в реанімачії (ФОТО)» («Волинська правда», 26.10.2018); «Кінотеатр «Адреналін» запрошує на украӥнську комедію про молодого ци амбітного дзідзьо» («Таблоїд Волині», 23.10.2018); «Музично-розважальна забава «Меломан» зібрала у луцькому пивному клубі аншлах» («Таблоїд Волині», 22.10.2018); «Кіноказку «Чорний козак» покажуть у кінотеатрі «Адреналін» («Таблоїд Волині», 23.10.2018); «Фермер з Волині отримав овець, яких він виграв на шоу «Громада на мільйон» («ВолиньРost», 18.10.2018).

6. Вияв занадтої емоційності: «У Луцьку патрульні затримали п'яних агресивних водіїв (ФОТО)» («Волинська правда», 27.10.2018); «З’явився фантастичний кавер на найпопулярнішу украӥнську пісню (ВІДЕО)» («Волинська правда», 21.10.2018);

7. Уживання не завжди унормованих лексем, термінів, незрозумілих читачам слів: «Наковталася таблеток: у Луиьку жінка намагалася вкоїми суїиид» («Волинська правда», 26.10.2018); «Мережа «Наш край» відкрила два нових магазини на умовах франчайзингу» («Таблоїд Волині», 23.10.2018)

8. Заголовок занадто абстрактний: «Таємниці газового дорожчання» («Волинська правда», 23.10.2018); «Лучан запрошують на баскетбол» («Таблоїд Волині», 23.10.2018)

9. Гіперболізація події «V ПортCity - наместя роботів» (у самому матеріалі сказано про виставку роботів) («Таблоїд Волині», 23.10.2018); «У Ковелі затримали нетверезого та агресивного водія» («Волинь Онлайн, 11.09.2018) 
10. Тавтологія: «У Луцьку молодь з усієї Украӥни говорила про молодіжні ичентри. Фото» («Таблоїд Волині», 24.10.2018).

11. Містить марковану або приховану рекламу: «Західний Олімп» пропонує сучасні квартири за доступними иінами» («ВолиньРоst», 18.10.2018); «У «Промені» відбудеться фестиваль анімації «Задзеркалля» («ВолиньРоst», 18.10.2018).

\section{Література:}

1. Майборода Л. І. До проблеми лаконічності та семантичної місткості газетних заголовків. Наукові записки Інституту журналістики. Київ, 2003. Т. 12. С. 59-63.

2. Майборода Л. І. Проблема композиційної функції газетних заголовків. Мовознавчий вісник : зб. наук. пр. Черкаси, 2006. Вип. 3. С. 279-287.

3. Майборода Л. І. Специфіка газетних заголовків до журналістських матеріалів різних жанрів. Вісник Черкаського університету. Серія «Філологічні науки». Черкаси, 2006. Вип. 94. С. 150-164.

4. Майборода Л. І. Типологія заголовків за їх інформаційною функцією. Лінгвістичні студї : зб. наук. пр. Черкаси, 2006. Вип. 2. С. $185-193$.

5. Михайленко В. Заголовковий комплекс як базовий елемент журналістського тексту. Наукові записки Інституту журналістики. 2013. Т. 50. Січень-березень. С. 239-244.

6. Ріпей М. В. Газетний заголовок: відповідність поліграфічним нормам. 3б. пр. Наук.-дослід. центру періодики. 2009. Вип. 2 (17). C. $447-453$.

7. Ріпей М. В. Особливості архітектоніки газетного заголовка. Вісник Львів. ун-ту. Серія «Журналістика». Львів : Вид-во Львів. нац. ун-ту ім. І. Франка, 2011. Вип. 35. С. 295-302.

8. Солодка Л. І. Лексико-семантичні особливості газетних заголовків : автореф. дис.... канд. наук із соціальних комунікацій. Київ, 2008. 14 с.

9. Солодка Л. Повтор газетного заголовка в медіатексті як засіб його лексико-семантичного увиразнення. Мовознавчий вісник : зб. наук. праць. Вип. 12-13. С. 268-273.

10. Шаповалова Г. В. Лексико-стилістичні особливості заголовків у сучасних українських друкованих ЗМІ. Уч. записки Таврич. нач. ун-та им. В. И. Вернадского. Серия "Филология. Социальные коммуникации». Симферополь, 2011. Т. 24 (63). № 4. Ч. 1. С. 204-210.

11. Шевченко В. Е. Заголовки як спосіб впливу на суспільну свідомість. Наук. записки Луган. наи. пед. ун-ту : [зб. наук. праць]. Серія 
«Філологічні науки» : у 3-х т. Луганськ : Альма-матер, 2004. Вип. 5. T. 1. C. 388-397.

12. Шевченко В. Е. Система рубрикації газети - основа іiі архітектонічної організації. Наук. записки Інституту журналістики. Київ, 2001. Т. 2. С. 53-69.

13. Шульська Н. М. Синтаксичні засоби оформлення заголовків журналістських текстів у волинських медіа. Літопис Волині: всеукраїнський науковий часопис. Луцьк: Волин. нац. ун-т ім. Лесі Українки, 2011. Ч. 10. С. 110-113.

14. Шульська Н. «Фактична брехня», або Про ще один різновид текстових анормативів у мові 3МІ. Південний архів: збірник наукових праць. Філологічні науки. Вип. 66. Херсон: Гельветика, 2017. С. 227-230. 